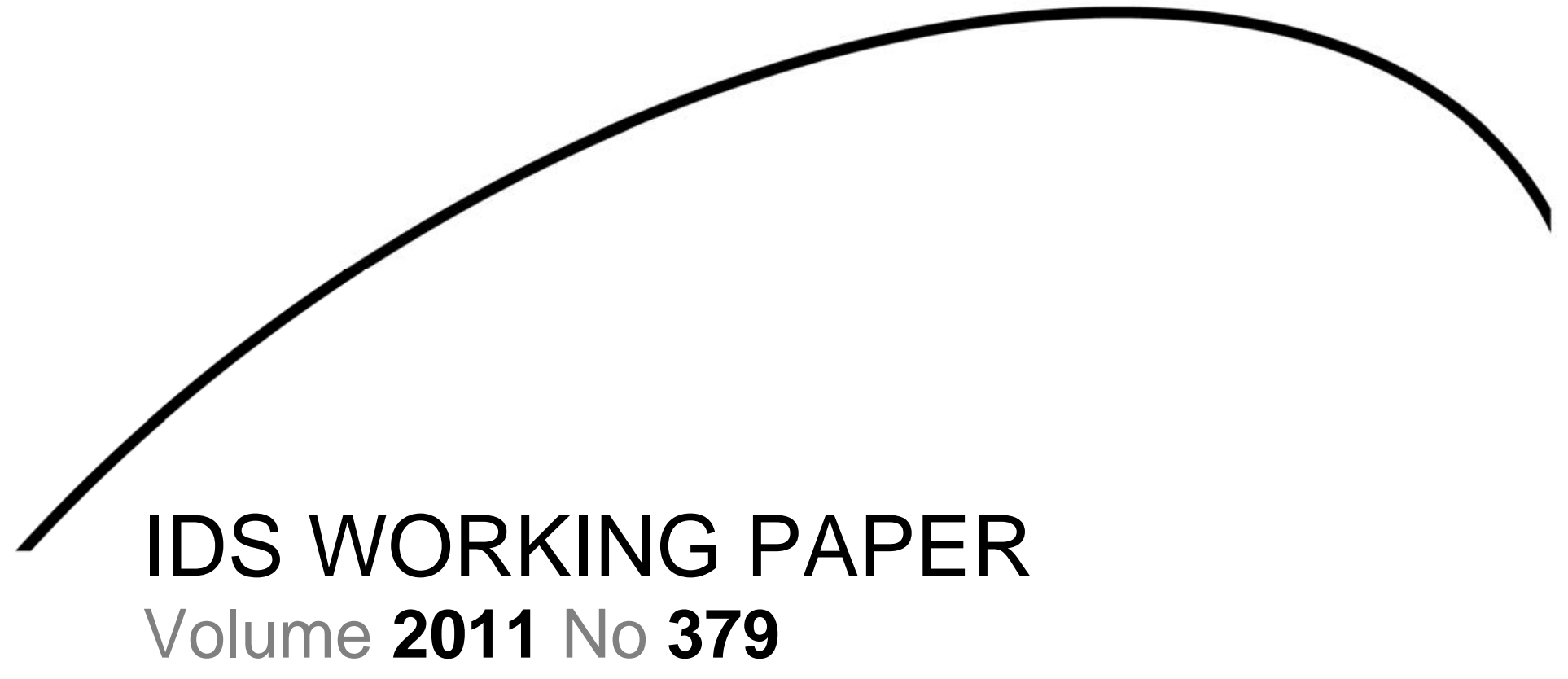

\title{
Violent Conflict and Human Capital Accumulation
}

Patricia Justino

November 2011

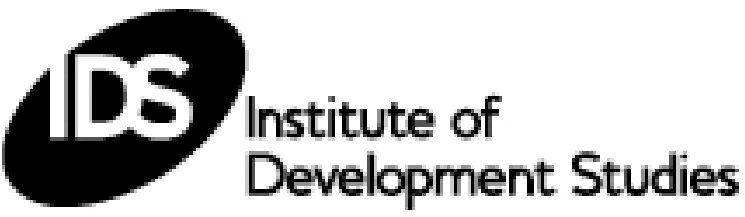


The Conflict, Violence and Development Research Cluster is part of the Vulnerability and Poverty Reduction Team at the Institute of Development Studies. The Cluster's main focus is to develop new insights into how people in contexts of conflict and violence live and interact, and what institutions help (or hinder) them. We aim to use our research findings to inform, identify and develop policies and practices that will strengthen people's own efforts to survive and make a living.

Email: conflict@ids.ac.uk

Web: www.ids.ac.uk/go/research-teams/vulnerability-and-poverty-reduction-team/researchthemes/conflict

\section{CVD WP1}

Violent Conflict and Human Capital Accumulation

Patricia Justino

IDS Working Paper 379

First published by the Institute of Development Studies in November 2011

(C) Institute of Development Studies 2011

ISSN: 1353-6141 ISBN: 978-1-78118-029-7

A catalogue record for this publication is available from the British Library.

All rights reserved. Reproduction, copy, transmission, or translation of any part of this publication

may be made only under the following conditions:

- with the prior permission of the publisher; or

- with a licence from the Copyright Licensing Agency Ltd., 90 Tottenham Court Road, London

W1P 9HE, UK,

or from another national licensing agency; or

- under the terms set out below.

This publication is copyright, but may be reproduced by any method without fee for teaching or nonprofit purposes, but not for resale. Formal permission is required for all such uses, but normally will be granted immediately. For copying in any other circumstances, or for reuse in other publications, or for translation or adaptation, prior written permission must be obtained from the publisher and a fee may be payable.

Available from:

Communications Unit, Institute of Development Studies, Brighton BN1 9RE, UK Tel: +44 (0) 1273915637

Fax: +44 (0) 1273621202

E-mail: bookshop@ids.ac.uk

Web: www.ids.ac.uk/ids/bookshop

IDS is a charitable company limited by guarantee and registered in England (No. 877338) 


\title{
Violent Conflict and Human Capital Accumulation
}

\author{
Patricia Justino
}

\section{Summary}

The objective of this paper is to review the available evidence on one important micro-level mechanism linking civil wars and long-term development outcomes, namely the level and access to education of civilian and combatant populations affected by violence. The paper is particularly concerned with the long-term human capital consequences of lost education.

Keywords: conflict; education; human capital.

Patricia Justino is a Research Fellow at the Institute of Development Studies, specialising in applied microeconomics. Her current research work focuses on the impact of violence and conflict on household welfare, the microfoundations of violent conflict and the implications of violence for economic development. She is the Director of MICROCON and co-founder and co-director of the Households in Conflict Network. Since June 2010, Patricia convenes the IDS Vulnerability and Poverty Reduction team cluster on Conflict, Violence and Development. 


\section{Contents}

Summary, keywords, author notes 3

Acknowledgements 4

Introduction $\quad \mathbf{5}$

1 Violent conflict and human capital accumulation:

theoretical considerations $\quad 5$

2 Violent conflict and human capital accumulation: the evidence so far $\quad 7$

3 Causal mechanisms linking violent conflict and educational outcomes 9

$\begin{array}{ll}3.1 \text { Child soldiering } & 10\end{array}$

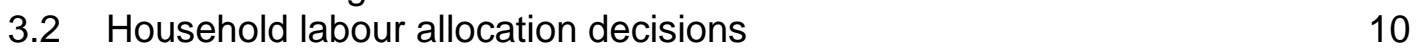

$\begin{array}{ll}3.3 & \text { Changes in returns to education } \\ 3.4 & 11\end{array}$

$\begin{array}{lll}3.4 & \text { Fear } & 11\end{array}$

3.5 Targeting of schools, teachers, students and staff 11

3.6 Displacement and forced migration 12

4 Conclusion 13

$\begin{array}{lr}\text { References } & 14\end{array}$

\section{Acknowledgements}

An earlier version of this paper entitled 'How Does Violent Conflict Impact on Individual Educational Outcomes? The Evidence So Far' appeared as a background paper for the Education For All Global Monitoring Report 2011 produced by UNESCO. The author is very grateful for discussions and comments from Pauline Rose, Anna Haas and Patrick Montjourides. Alexander Cornelius provided excellent research assistance.

This paper first appeared as MICROCON Research Working Paper 54 in October 2011. MICROCON was a five-year European Commission FP6 research programme, running from 2007 to 2011. It took an innovative micro level, multidisciplinary approach to studying the conflict cycle, promoted understanding of individual and group interactions leading to and resulting from violent mass conflicts, and aimed to better inform conflict policy and place individuals and groups at the centre of interventions. For more information please visit the website www.microconflict.eu/

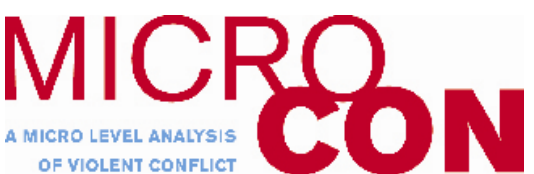




\section{Introduction}

Violent conflict is one of the most important development challenges facing the world today. Although the incidence of civil wars has decreased in recent years (Harbom and Wallensteen 2009), the legacy of violence persists across many countries around the world, especially in Africa, Caucasia, the Balkans, and the Middle East. The economic, political and social consequences of civil wars are immense. War displaces people, destroys capital and infrastructure, disrupts schooling, damages the social fabric, endangers civil liberties, and creates health and famine crises. Almost 750,000 people die as a result of armed conflict each year (Geneva Declaration Secretariat 2008), and more than 20 million people were internally displaced by civil wars at the end of 2007 (UNHCR 2008). Any of these effects will have considerable consequences for long-term development outcomes. Yet while there is a growing consensus that development interventions and the promotion of democracy worldwide cannot be disassociated from the restrictions caused by violent conflict, we have limited rigorous evidence on how violent conflict affects development outcomes, the economy or the lives of people exposed to violence.

One fundamental mechanism by which violent conflict may affect log-term development outcomes is through the accumulation of human capital, a central mechanism in economic growth and development processes (Galor and Weil 2000; Lucas 1988, 2002; Schultz 1961). The objective of this paper is to review the available evidence on one important micro-level mechanism linking civil wars and long-term development outcomes, namely the level and access to education of civilian and combatant populations affected by violence. The paper is particularly concerned with the long-term human capital consequences of lost education.

\section{Violent conflict and human capital accumulation: theoretical considerations}

From a theoretical point of view, the long-term developmental effects of violent conflict are unclear. Neoclassical models predict rapid catch-up growth in the post-conflict period as the economy converges to its steady state growth rate. In particular, the temporary destruction of capital can be overcome in the long-term by higher investments in affected areas that will bring the overall economy to its steady growth path (see discussion in Blattman and Miguel 2010 and Bellows and Miguel 2006). Davis and Weinstein (2002), employing a unique dataset on Japanese regional population, look at the effects of the Allied bombing of Japanese cities during World War II. Their findings reveal that cities that suffered the largest population declines due to the bombing tended to have the fastest post-war growth rates. The typical city in Japan affected by the bombings recovered its former relative size fully within 15 years following the end of World War II. Brakman, Garrtesen and Shramm (2004) arrive at similar conclusions in their analysis of the impact of the bombing of German cities during WWII on post war German city growth. Miguel and Roland (2006) present similar findings using the extensive variation in US bombing intensity across 584 districts in Vietnam. Their results show that the bombing had no long-term impact on economic growth across regions in Vietnam affected by the war. Justino and Verwimp (2006) find evidence for this form of convergence across provinces in Rwanda following the 1994 genocide. Chen Loayza and Reynal-Querol (2008) find, across a sample of 41 countries that experienced civil war between 1960 and 2003, that once civil war ends, recovery in economic performance, health, education, and political development increases significantly. Other cross-country studies literature reiterate these findings of rapid economic recovery in postwar economies (see Cerra and Saxena 2008; Organski and Kugler 1977, 1980; Przeworski et al. 
2000). Civil wars may also promote state formation and nation building as was the case in Europe (Tilly 1978, 1990), and may induce social progress via greater popular participation in civic and political institutions (Blattman 2008; Bellows and Miguel 2006; Wood 2003).

Other studies point to the long-term destructive effects of civil wars that may remain entrenched in certain regions even if economic growth converges at the aggregate level. Civil wars break social cohesion (Collette and Cullen 2000), destroy infrastructure and create political instability and insecurity in property rights (ERD 2009; OECD 2009). The destruction entailed by warfare, combined with the erosion of institutions and organizations, leads to a deterioration of the economic environment. This in turn leads to a reduction in the desired levels of factors of production. Some factors (such as physical and human capital) are more able to leave the country than others (such as arable land), giving rise to a gradual exodus of these more mobile factors (Collier 1999). Violent conflict may also affect severely the quality and functioning of institutions, the expansion of technology and social outcomes (Blattman and Miguel 2010; Acemoglu and Robinson 2006). In particular, recent research on the microlevel effects of violent conflict has shown that negative impacts of civil wars on education, labour and health of individuals and households can be observed decades after the conflict (Alderman, Hoddinott and Kinsey 2006; Bundervoet, Verwimp and Akresh 2009; Shemyakina 2006). Although these effects may average out at the macroeconomic level, they may contribute to the emergence of poverty traps amongst specific population groups affected by violence (Justino 2009, 2010).

The impact of war on the accumulation of human capital amongst civilian populations affected by violence can be substantial and persistent. Not only do people living in war zones suffer injuries, death and have their property destroyed, they may also be displaced from their homes and lose their means of survival. Children are especially adversely affected by the destruction of physical capital and the deterioration of economic conditions given the age-specific aspects of many human capital investments. Civil wars and associated physical destruction can interrupt the education of children through the damage to schools, absence of teachers, fears of insecurity and changes in family structures and household income. Children can also be negatively affected by the worsening of their health due to the association of violent conflict with famines, widespread malnutrition, outbreaks of infectious diseases, post-war trauma, and the destruction of health facilities. The destruction of human capital during childhood is a well-documented mechanism leading to poverty traps, given the severe long-run effects it can have on individual and household welfare via the future labor market outcomes and economic performance of affected children (see Mincer 1974; Shultz 1961; Becker 1962).

These micro-level effects of civil wars remain largely under-researched. This is unsurprising given that large-scale, high quality micro-level level data for developing countries affected by civil war is generally not available. When it is available it is difficult to identify whether and under which circumstances household coping behaviour is induced by civil war events or by other economic conditions that may have taken place simultaneously (see discussion in Verwimp, Justino and Brück 2009). Detailed measures of conflict and associated destruction are often not available, and such information is difficult to collect from countries that have just emerged or are emerging from armed conflict. In the next section, we discuss in more detail the available empirical evidence on the impact of violent conflict on education. Section 3 explores the different mechanisms that may link the outbreak of violent conflict with educational outcomes, an area that has remained unexplored in the literatures on conflict and on education. 


\section{Violent conflict and human capital accumulation: the evidence so far}

Violent conflict results in deaths, injuries, disability and psychological trauma to men, women and children. These outcomes of violence may often be enough to push previously vulnerable households below critical thresholds. These may become impossible to overcome if the household is unable to replace labour or capital, and may last across generations if the impact on children's education and health is significant (Case and Paxson 2006; Maccini and Young 2009). Below we review emerging empirical literature on the impact of violent conflict on educational outcomes amongst children and young men and women affected by violence.

For a long time, research on the consequences of violent conflict focused on estimating the aggregate costs that civil wars impose on countries (e.g. Knight et al. 1996; Collier 1999; Stewart and Fitzgerald 2001). Programmes of conflict resolution have also been typically driven by concerns with state security and state capacity (see UN 2004, 2005). This countrylevel perspective has come under criticism in recent years due to insufficient attention paid to the impact of armed conflicts on the lives of individuals and households affected by violence (see Justino 2009; Verwimp, Justino and Brück 2009). Better data and improvements in microeconomic research in developing countries have led in recent years to an increased focus of research and policy on the consequences of violent conflict on the long-term human capital of people affected by violence (see review in Justino 2010).

Although still in its infancy, emerging empirical evidence on the micro-level effects of violent conflict has found that in general civil wars have a negative impact on educational attainments. Alderman, Hoddinott and Kinsey (2006) find that Zimbabwean children affected by the civil war in the 1970 s completed less grades of schooling and/or started school later than those not affected by the shocks. Similar results are found by Akresh and de Walque (2008) for Rwanda, Angrist and Kugler (2008) and Rodriguez and Sanchez (2009) for Colombia, Chamarbagwala and Morán (2009) for Guatemala, de Walque (2006) for Cambodia, Shemyakina (2006) for Tajikistan and Swee (2009) for Bosnia.

As with any new area of research, results are still ambiguous and generally not yet comparable. For example, Shemyakina (2006) finds from her empirical work in Tajikistan, that it is girls who suffer the greatest loss in education due to concerns over safety and low returns to girls' education. In contrast, Akresh and de Walque (2008) find that, in Rwanda, it is amongst the male children in non-poor households that these negative shocks are strongest, potentially due to a levelling off of educational achievements to a low level for everyone. Some consistent patterns have however started to emerge.

The first is that relatively minor shocks to educational access can lead to significant and longlasting detrimental effects on individual human capital formation in terms of educational attainment, health outcomes and labour market opportunities. Akbulut-Yuksel (2009) provides causal evidence on the long-term consequences of large-scale physical destruction caused by WWII on the educational attainment, health status and labour market outcomes of German children. This study combines a unique dataset on city-level destruction in Germany caused by Allied Air Forces bombing during WWII, with individual survey data from the German Socio-Economic Panel (GSOEP). She finds significant, long-lasting detrimental effects of bombing on human capital, health and labour market outcomes of individuals who were at school-age during WWII. Sixty years after the end of the war, these individuals had 0.4 fewer years of schooling on average in adulthood in comparison to those not affected by the bombings. Those in the most hard-hit cities completed 1.2 fewer years of schooling in relation to those not affected by the bombings. They were also about one centimetre shorter 
and had lower self-reported health satisfaction in adulthood. Despite the seemingly small educational impact of war exposure (between 0.4 and 1.2 years on average), individuals that as children lived in areas of high intense bombing experienced on average a very significant reduction of 6 per cent in labour market earnings in relation to those not affected by the bombings. Another piece of research which resonates with these findings is that of Ichino and Winter-Ebner (2004). This paper shows that in two European countries involved in WWII - Austria and Germany - children who were ten years old during the conflict were significantly less likely to proceed into higher education and lost around 20 per cent of a year of schooling on average. No effect is found for individuals in the same cohorts living in countries not involved in the war. Their results show that the negative educational effects of the war, and consequent reduction in earnings, led to GDP in Germany being at least 0.36 per cent lower in 1986 than what it should have been without the war. The loss for Austrian GDP in 1983 is larger, around 0.67 per cent. Merrouche (2006) adds to these findings with an interesting piece of research on the long-run effects of land mine contamination on human capital in Cambodia after 30 years of war during the Khmer Rouge regime. Cambodia is one of the most heavily land mine contaminated countries in the world, with about one mine planted for each inhabitant. The study finds that land mine contamination has caused significant educational losses in Cambodia. A conservative estimate at the mean level of landmine exposure suggests a loss of about 0.4 years of education. This again represents a very large education setback given a sample average number of years of education of about 4.5 years in 1997.

The second pattern emerging from this area of research is that the destruction of infrastructure, the absence of teachers and reductions in schooling capacity during violent conflicts across the world see to have affected secondary schooling disproportionately. Chen Loayza and Reynal-Querol (2008) find that the average recovery rate for primary-school enrolment in the period between 1960 and 2003 was larger than that of secondary enrolment in post-conflict countries. Stewart et al. (2001) find that primary school enrolments decreased in only three out of eighteen countries in their sample of countries affected by civil wars. These effects recur also in micro-level studies. Akresh and De Walque (2008) examined the impact of Rwanda's 1994 genocide on children's schooling. They find that school age children exposed to the genocide experienced a drop in educational achievement of almost half a year of completed schooling, and are 15 per cent less likely to complete $3^{\text {rd }}$ or $4^{\text {th }}$ grade. The most likely mechanism linking the genocide to educational attainment is through lack of progression to higher secondary schooling grades. Swee (2009) provides evidence on the effects of the civil war in Bosnia (1992-1995) on schooling attainment of the cohorts who were in the process of completing their primary and secondary schooling during the war. $\mathrm{He}$ finds that individuals in cohorts affected by the civil war are less likely to complete secondary schooling if they resided in municipalities which experienced higher levels of war intensity. He finds no noticeable effects on primary schooling, which might indicate successful organisation of war schools at the primary level. Swee argues that youth soldiering may be the key mechanism explaining these effects.

The third pattern is that the exposure of households to violence results in significant gender differentials in individual educational outcomes. Shemyakina (2006) examines the effects of the armed conflict (1992-1998) in Tajikistan. Her results indicate that exposure to the conflict had a large, significant and negative effect on the enrolment of girls. She observes little or no effect on the enrolment of boys. Girls who were of school age and during the conflict, and lived in conflict-affected regions, were 12.3 per cent less likely to complete mandatory schooling as compared to girls who completed their schooling before the conflict started. They are also 7 per cent less likely to complete school than girls of the same age who lived in regions relatively unaffected by the civil war. Furthermore, Shemyakina finds that the probability of completing the mandatory nine grades is 4 per cent and 7 per cent lower for boys and girls, respectively. The probability decreases by another 5 per cent for girls born between 1978 and 1986 that lived in regions affected by the conflict during their schooling 
years. These results suggest that households affected by conflict invested more in the schooling of boys, for whom there is less perceived risk of violence, harassment or abduction. Due to the destruction of industries and infrastructure, job opportunities for skilled labour may become scarce, in which case it may make more economic sense to educate boys as they may be more likely than girls to take up higher paid jobs. In a similar paper, Chamarbagwala and Morán (2009) examines how the worst period of the civil war in Guatemala (1979-1984) affected human capital accumulation amongst affected children. This study examines the effects of war on years of schooling and grade completion amongst different social groups. Similarly to Shemyakina's, this empirical analysis exploits variation in war intensity across departments and across cohorts at school age during the war. The results show a strong negative impact of the civil war on female education. Girls exposed to the 1979-1984 war during their school-age years completed 0.44 years of school (or 12 per cent) less than girls living in departments not affected by the fighting. Older female cohorts exposed to the war completed 0.64 years (17 per cent) less schooling than those not affected by warfare. The effect for males is smaller. Female education continued to lag behind male education throughout the country, but especially so in the areas which of high war intensity between 1979 and 1984, almost two decades after the worst conflict outbreak (in 2002). The study suggests that loss of property and massive displacement led households to reallocate limited resources towards providing young boys and, to a lesser extent, young girls, with at least some primary education. While both boys and girls received less secondary and high school education as a result of the civil war, the effects were more pronounced for girls. As in the Tajikistan study, considerations regarding higher education returns for boys and fear of abduction and rape of girls may explain these results. Similarly to Akresh and de Walque (2008), Chamarbagwala and Morán find that a lower probability of progressing from one grade to another rather than not attaining any education appears to drive the results.

\section{Causal mechanisms linking violent conflict and educational outcomes}

The literature reviewed above shows a clear negative legacy of violent conflict on the human capital of individuals (and consequently of families) exposed to violence. Amongst the results discussed, a debate has emerged as to what causal mechanisms explain the negative link between violent conflict and educational outcomes. While it is clear that civil wars affect household education attainment and schooling decisions, it is much less apparent through which channels and for how long these effects will impact on the long-term ability of individuals and households to survive economically, access sustainable forms of livelihood, and make long-term production, consumption or labour decisions. More research therefore needs to be done in terms of uncovering the precise mechanisms through which the relationship operates. Detailed knowledge of the mechanisms that support this negative relationship between conflict and educational outcomes are crucial towards creating and implementing effective policy to ensure these negative consequences are dampened.

Civil wars affect negatively educational outcomes because, during violent conflict, children are either removed from school, are prevented from attending school or the conditions under which they attend school do not provide them with education of sufficient quality. Below we discuss several types of mechanisms that explain the absence or reduction in schooling of children affected by fighting. We discuss below six possible mechanisms: soldiering, household labour allocation decisions, fear, changes in returns to education, targeting of schools, teachers and students and displacement. 


\subsection{Child soldiering}

The recruitment of child soldiers is a tactic used widely by armies and rebel groups alike to increase the number of fighters, improve logistical support, spread fear and reduce resistance amongst local populations. Children in armies are used as fighters, porters, messengers, cooks and are often forced to provide sexual services (USAID 2007). It is believed that violent conflicts around the world have involved around 300,000 children, both boys and girls, under the age of 18 (Blattman et al. 2007; World Bank 2005). Most of the (few) available empirical studies of child soldiers focus on boys, although there is wide recognition of the involvement of girls in armed forces, as combatants and as noncombatants (used as cooks, cleaners, nurses and so forth), and as victims of sexual slavery, forced 'marriages', rape and other forms of sexual violence (UNHCR 2002; Annan et al. 2009). Estimates from 2005 suggest that of the approximately 300,000 child soldiers involved in combat worldwide, 40 per cent of them are girls (Save the Children 2005). The military recruitment of children, either by armed non-state groups or national armies, is however still widely underreported, taking place in a variety of forms in over 86 countries and territories worldwide (USAID 2007).

The recruitment of children into armed groups and armies has considerable impacts on their educational attainment, with consequences on their level of human capital. In particular, participation in armed groups affects negatively the long-term economic performance of child soldiers in terms of skills, productivity and earnings because military activities are not good substitutes for the benefits that individuals will acquire through education and work experience (Blattman and Annan 2007). Boys and girls exposed to conflict may also experience severe psychological effects that may continue long after the war is over and affect their educational outcomes. Weak economic opportunities in turn may serve to exacerbate the conflict if individuals have more to gain from soldiering when peacetime economic opportunities are limited (Grossman 2002; Walter 2004).

\subsection{Household labour allocation decisions}

Households in conflict-affected countries tend replace dead, injured or physically and mentally disabled adult workers with children, if these have not become fighters themselves, in order to compensate for the unexpected reduction in the financial resources available to households during wartime. The use of children as a form of economic security mechanism is widely reported in the development economics literature (see Dasgupta 1993; Nugent and Gillaspy 1983), as is the resort to child labour as a form of compensating for low-incomes (Basu and Van 1998; Duryea, Lam and Levinson 2007). In India, for example, agricultural households use seasonal school non-attendance by children and child labour as a form of self-insurance in the lean times (Jacoby and Skoufias 1997). Similarly, in Indonesia, many households were forced to decrease their spending on education after the 1998 financial crisis (Thomas et al. 2004). These studies assume that households in general favour investing in the education of their children. However, when facing unexpected income shocks, households tend to trade-off future consumption with maintain current consumption (often food) levels. Income uncertainty may therefore adversely affect the quality and quantity of children's education, and have severe negative consequences on the long-term welfare of households.

Children that are needed to replace labour may be removed from school, which may in turn deplete the household of their stock of human capital for future generations. Akresh and de Walque (2009), Merrouche (2006), Shemyakina (2006) and Swee (2009) point to this mechanism as an explanation for the reduction in educational attainment and enrolment observed in contexts of civil war. In a recent paper, Rodriguez and Sanchez (2009) test directly the effect of war on child labour and find that violent attacks in Colombian municipalities by armed groups have increased significantly the probability of school drop- 
out, and have increased the inclusion of children in the labour market. They show that increased mortality risks, negative economic shocks and reduction in school quality due to violence are the main channels through which armed conflict reduces human capital investments at the household level and increases child labour.

The social legacy of the conflict becomes even more profound when we remember that data allows us to observe information only on those individuals who survive the conflict. In addition, poor individual health and the loss of family members may create serious restraints on access to schooling. In one such study, Evans and Miguel (2004) find that young children in rural Kenya are more likely to drop out of school after the parent's death and that effect is particularly strong for children who lost their mothers.

\subsection{Changes in returns to education}

Violent conflict may affect considerably the level and distribution of returns to education across social groups and gender. Returns to education in turn play a large role in households' decisions. Due to destruction of industries and infrastructure, job opportunities for skilled labour in conflict-affected countries generally become scarce. Households may respond to job scarcity by redistributing their resources away from investments with lower returns. In wartime contexts, this may mean investing more in the education of boys rather than girls as boys may have a higher probability of finding better paid jobs. This effect is found in Shemyakina (2006) and Chamarbagwala and Morán (2009), as discussed above. Evidence on how this mechanism operates in different conflicts and across different population groups is however still scarce.

\subsection{Fear}

Fear plays an important part in explaining the removal of children from schools during violent events. A recently reported fighting strategy in Afghanistan has been the direct targeting of school children on their way to or from school. More than 100 children were killed in this way between 2006 and 2008, according to UNICEF. This tactic for spreading fear has resulted in the closure of around 670 schools in early 2009, depriving around 170,000 children of access to education (IRIN 2009). Rape and other sexual violence are common behaviour amongst fighting groups (IRIN 2004). Fear of physical attacks and sexual violence is likely to hinder the ability of children, particularly although not exclusively girls, to enrol in schools. In such contexts of fear and terror, households may attempt to protect vulnerable members by keeping them at home or sending away to relatives and friends in more secure locations.

\subsection{Targeting of schools, teachers, students and staff}

In several conflict-affected countries, access to good quality education is seriously imperilled, not only due to the direct effects of fighting, but also because schools, teachers, students and staff are often targeted by violent attacks. The types of attack include the burning, shelling and bombing of schools, the occupation of schools by armed forces, the murder, torture, abduction and rape of teachers, students, education aid workers and school staff by armed groups or military forces, and the forced recruitment of child soldiers (O'Malley 2007, 2010). These attacks lead to the death of teachers and students, the destruction of infrastructure, and result also in severe psychological trauma to those exposed to them. In face of repeated incidents and threats of attack, children are afraid to go to school, parents will be scared of sending them to school and teachers will be afraid to go to work. Schools will be closed to prevent attacks (IANS 2009), and governments may be reluctant to reopen schools because threats of attack may still be present (Mulkeen 2007). They will also find it difficult to replace teachers in the areas targeted (Mulkeen 2007). Motives for these attacks on schools, students and staff vary according to circumstances. In some cases, schools are the only visible symbol of government rule, making them easy targets for rebel groups (O'Malley 2007). Attacks are also used as a form of control of the population to impose 
religious, linguistic or cultural identities (Human Rights Watch 2006), and to recruit personnel, or provide shelter for troops (O'Malley 2010). Teachers are also perceived as leaders of communities. Threats and attacks to teachers tend to take place due to their opposition to the forced recruitment of children by armed groups, their positions of leadership in the community, and accusations they face by armed groups of collaborating with opposing groups (Novelli 2008; Amnesty International 2007). All these effects will have long term consequences for the type and quality of schooling available to children in areas of violence.

\subsection{Displacement and forced migration}

More than 27 million children are estimated to be out of education as a result of emergency situations. A large proportion of these are internally displaced (Mooney and French 2005). Displaced children are deprived of education but also of the support provided by educational structures in difficult, often persistently violent, environments. Access to education is an important element to the successful integration of internally displaced populations into their communities as the disruption to normal life and insecurity inherent in refugee and displacement camps can harm children's physical, intellectual, psychological, cultural and social development with long term consequences to their welfare and that of their children (UNHCR 1994: 38-9).

Education is increasingly viewed as the 'fourth pillar' of humanitarian response, alongside nourishment, shelter and health services (ICWAC 2000). Education can help to reduce children's exposure to threats including sexual exploitation, physical attack and recruitment into armed groups. Classrooms can also be effective means to disseminate information on how to avoid landmines, reducing the risk of HIVIAIDS and other preventive measures. Access to education may also facilitate the integration of displaced populations into local communities as schools may provide a means to promote community cohesion.

Very often education is viewed as a long term post-conflict development aim and does not constitute a central element in emergency interventions amongst displaced populations. However, violent conflict and resulting displacement can last decades leaving whole generations without access to education and the social structures provided by schools and teachers. The availability of education in IDP camps is typically disorganised, when it exists at all. Where schools do exist they tend to be temporary, under-resourced, overcrowded and limited to primary education. Accessing schools outside the camps may not be an option due to issues of safety. The loss or confiscation of personal documents also makes enrolment difficult for displaced populations (Aguilar et al. 1998). School fees, the cost of school supplies and travel costs may also pose constraints to the access of education by displaced children (UNHCR/OSCE 2002). While some governments have implemented fee waivers for displaced children, these policies are rarely observed.

In addition, displaced children do not attend school when their labour is needed to contribute to household income. Boys are employed in farming and other activities, while girls are needed to help with domestic work, childcare and agricultural tasks. For those that do manage to get schooling while still working, there are losses in the quality of their education due to chronic fatigue and stress (Brookings Institution-SAIS Project on Internal Displacement 2003). In Colombia, where in 1999 only an estimated 15 per cent of IDP children received some form of education, the academic performance was found to be significantly constrained by high rates of malnutrition, trauma and cognitive disorders (Profiles in Displacement: Colombia, cited in Mooney and French 2005). 


\section{Conclusion}

This paper provided a review of available empirical evidence on the impact of violent conflict, largely civil wars, on education outcomes amongst civilian and combatant populations affected by violence. The literature reviewed shows a clear negative legacy of violent conflict on the educational outcomes of individuals and households exposed to violence. Three main themes emerge from existing empirical literature. The first is that even relatively minor shocks to a population's level of education can cause significant and long-lasting detrimental effects on human capital formation. These effects persist well after the conflict has ended, with long-term intergenerational consequences in terms of school achievement, health outcomes and future earnings. Secondly, violent conflict seems to affect secondary schooling more critically than primary schooling (Swee 2009; Shemyakina 2006). This might indicate successful organisation of war schools at the primary level, and an indication that families and organisations try to give their children at the very least some primary education even in circumstances of persistent violence. Thirdly, education effects are not gender neutral. Conflict can change social, economic and political relations in such a way that makes returns to schooling for some social groups (usually girls) less attractive (Shemyakina 2006; Chamarbagwala and Morán 2009). Due to the destruction of industries and infrastructure, job opportunities for skilled labour, particularly women, may become scarce leading households to value the education of boys higher than that of girls. The vulnerability of girls to sexual attacks and abduction may also explain the lower educational attainment of girls observed during violent conflict.

Evidence on the specific casual mechanisms that mediate these effects is scarce. The analysis of empirical studies and policy reports allowed us to review some important channels reported in the relevant literature, with important policy implications. These include the recruitment of child and youth soldiers, the need of children to contribute to household income, changes in returns to education during conflict, fear and attacks and displacement. Evidence on these channels, as well as the patterns emerging from recent empirical research, point to the importance of human capital accumulation for the wellbeing and economic outcomes amongst households and individuals affected by armed conflict and violence. We expect more to emerge as this area of research matures and we come to a better understanding of what specific factors are likely to affect education, who it is likely to be effected and the causal pathways through which these changes occur in order to help policy-makers to more effectively deal with the loss of education that violent conflict inflicts. 


\section{References}

Aguilar, P. and Retamal, G. (1998) Rapid Educational Response in Complex Emergencies: A Discussion Document, Geneva: International Bureau of Education

Akbulut-Yuksel, M. (2009) Children of War: The Long-Run Effects of Large-Scale Physical Destruction and Warfare on Children, IZA Discussion Paper 4407, September, Bonn: The Institute for the Study of Labor

Akresh, R. and de Walque, D. (2008) Armed Conflict and Schooling: Evidence from the 1994 Rwandan Genocide, IZA Discussion Paper 3516, May, Bonn: The Institute for the Study of Labor

Alderman, H.; Hoddinott, J. and Kinsey, B. (2006) 'Long Term Consequences of Early Childhood Malnutrition', Oxford Economic Papers 58.3: 450-74

Amnesty International (2007) Colombia Killings, Arbitrary Detentions, and Death Threats The Reality of Trade Unionism in Colombia, Report (AI Index: AMR 23/001/2007), July, London

Angrist, J.D. (1990) 'Lifetime Earnings and the Vietnam Era Draft Lottery: Evidence from Social Security Administrative Records', American Economic Review 80.3: 313-36

Angrist, J.D. and Krueger, A.B. (1994) 'Why Do World War II Veterans Earn More than Nonveterans?', Journal of Labor Economics 12.1: 74-97

Annan, J.; Blattman, C.; Mazurana, D. and Carlson, K. (2009) Women and Girls at War: 'Wives', Mothers and Fighters in the Lord's Resistance Army, HiCN Working Paper 63, Households in Conflict Network, www.hicn.org

Becker, G.S. (1962) 'Investment in Human Capital: A Theoretical Analysis', Journal of Political Economy 70.5 Part 2: 9-49

Ben-David, D. and Papell, D. (1995) 'The Great Wars, the Great Crash, and the Unit Root Hypothesis', Journal of Monetary Economics 36: 453-75

Blattman, C. and Annan, J. (2007) The Consequences of Child Soldiering, HiCN Working Paper 22, Households in Conflict Network, www.hicn.org

Brakman, S.; Garretsen, H. and Schramm, M. (2004) 'The Strategic Bombing of German Cities During World War II and Its Impact on City Growth', Journal of Economic Geography 4.2: 201-18

Brookings Institution-SAIS (2003) Project on Internal Displacement, Report of the Experts Meeting at the Conference on Internal Displacement in the IGAD Sub-Region, Khartoum, Sudan, 20 August-2 September

Bundervoet, T.; Verwimp, P. and Akresh, R. (2007) Health and Civil War in Rural Burundi, IZA Discussion Paper 2951, July, Bonn: The Institute for the Study of Labor

Cerra, V. and Saxena, S.C. (2008) 'Growth Dynamics: The Myth of Economic Recovery', American Economic Review 98.1: 439-57 
Chamarbagwala, R. and Morán, H. (2008) The Human Capital Consequences of Civil War: Evidence from Guatemala, HiCN Working Paper 59, Households in Conflict Network, www.hicn.org

Chen, S.; Loayza, N.V. and Reynal-Querol, M. (2008) 'The Aftermath of Civil War', World Bank Economic Review 22.1: 63-85

Collier, P. (1999) 'On Economic Consequences of Civil War', Oxford Economic Papers 51.1: 168-83

Davis, D.R. and Weinstein, D.E. (2002) 'Bones, Bombs, and Break Points: The Geography of Economic Activity', American Economic Review 92.5: 1269-89

ERD (2009) Overcoming Fragility in Africa: Forging a New European Approach, European Report on Development, Schuman Centre for Advanced Studies, European University Institute, San Domenico di Fiesole

Evans, D.K. and Miguel, E. (2004) 'Orphans and Schooling in Africa: A Longitudinal Analysis', unpublished manuscript, Bureau for Research and Economic Analysis of Development, Harvard University, Cambridge, MA

Galor, O. and Weil, D. (2000) 'Population, Technology, and Growth: From Malthusian Stagnation to the Demographic Transition and Beyond', American Economic Review 90.4: 806-28

Geneva Declaration Secretariat (2008) Global Burden of Armed Conflict, Geneva Declaration, Geneva

Grossman, H.I. (2002) 'Make Us a King: Anarchy, Predation, and the State', European Journal of Political Economy 18.1: 31-46

Harbom, L. and Wallensteen, P. (2009) 'Armed Conflicts, 1946-2008', Journal of Peace Research 46.4: 577-87

Human Rights Watch (2006) Thailand: Insurgent Attacks Shut Down Schools in South, HRW press release, 28 November

Ichino, A. and Winter-Ebmer, R. (2004) 'The Long-Run Educational Cost of World War II', Journal of Labor Economics 22.1: 57-86

ICWAC (2000) 'Caught in the Crossfire No More: A Framework for Commitment to WarAffected Children', Summary by the Chairs of the Experts at The International Conference on War-Affected Children, 13-15 September, Winnipeg

IRIN (2004) Our Bodies, Their Battleground: Gender-Based Violence in Conflict Zones, Integrated Regional Information Networks (IRIN) Web Special on violence against women and girls during armed conflict, September

Jacoby, H.G. and Skoufias, E. (1997) 'Risk, Financial Markets, and Human Capital in a Developing Country', Review of Economic Studies 64.3: 311-35

Justino, P. (2009) 'Poverty and Violent Conflict: A Micro-Level Perspective on the Causes and Duration of Warfare', Journal of Peace Research 46.3 
_ (2010) 'War and Poverty', in Michelle Garfinkel and Stergios Skaperdas (eds), Handbook of the Economics of Peace and Security, Oxford: Oxford University Press

Justino, P. and Verwimp, P. (2006) Poverty Dynamics, Violent Conflict and Convergence in Rwanda, HiCN Working Paper 16, Households in Conflict Network, www.hicn.org

Lucas, R.E., Jr. (1988) 'On the Mechanics of Economic Development', Journal of Monetary Economics 22.1: 3-42

— (2002) Lectures on Economic Growth, Cambridge: Harvard University Press

Novelli, M. (2008) Colombia's Classroom Wars: Political Violence against Education Sector Trade Unions in Colombia, Brussels: Education International

Merrouche, O. (2006) The Human Capital Cost of Landmine Contamination in Cambodia, HiCN Working Paper 25, Households in Conflict Network, www.hicn.org

Miguel, E. and Roland, G. (2006) The Long Run Impact of Bombing Vietnam, National Bureau of Economic Research Working Paper 11954, January, Cambridge, MA

Mincer, J. (1974) Schooling, Experience and Earnings, New York: National Bureau of Economic Research

Mooney, E. and French, C. (2005) Barriers and Bridges: Access to Education for Internally Displaced Children, The Brookings Institution, University of Bern

Mulkeen, A. (2007) Recruiting, Retraining and Retaining Secondary School Teachers in SubSaharan Africa, World Bank Working Paper 99, Washington DC

OECD (2009) Conflict and Fragility: Armed Violence Reduction - Enabling Development, OECD Development Co-operation Directorate Policy Analysis, Paris

O'Malley, B. (2007) 'Education Under Attack': A Global Study on Targeted Political and Military Violence against Education Staff, Students, Teachers, Union and Government Officials, and Institutions, report commissioned by UNESCO, Education Sector, Division for the Co-ordination of United Nations Priorities, 27 April

- (2010) Education Under Attack, report commissioned by Division for the Coordination of United Nations Priorities in Education, Education Sector, UNESCO

Organski, A.F.K. and Kugler, J. (1977) 'The Costs of Major Wars: The Phoenix Factor', American Political Science Review 71.4: 1347-66

_ (1980) The War Ledger, Chicago: University of Chicago Press

Przeworski, A.; Alvarez, M.E.; Cheibub, J.A. and Limongi, F. (2000) Democracy and Development: Political Institutions and Wellbeing in the World 1950-1990, Cambridge: Cambridge University Press

Save the Children UK (2005) Forgotten Casualties of War: Girls in Armed Conflict, Report, April

Shemyakina, O. (2006) The Effect of Armed Conflict on Accumulation of Schooling: Results from Tajikistan, HiCN Working Paper 12, Households in Conflict Network, www.hicn.org 
Schultz, T.W. (1961) 'Investment in Human Capital', American Economic Review 51.1: 1-17

Stewart, F.; Huang, C. and Wang, M. (2001) 'Internal Wars in Developing Countries: An Empirical Overview of Economic and Social Consequences', in F. Stewart, and V. FitzGerald (eds), War and Underdevelopment, Volume 1, Oxford: Oxford University Press

Swee, E. (2009) On War and Schooling Attainment: The Case of Bosnia and Herzegovina, HiCN Working Paper 57, Households in Conflict Network, www.hicn.org

Tilly, C. (1978) From Mobilization to Revolution, New York: McGraw-Hill

— (1990) Coercion, Capital, and European States, AD 990-1990, Oxford: Blackwell

Thomas, D.; Beegle, K.; Frankenberg, E.; Sikoki, B.; Strauss, J. and Teruel, G. (2004) 'Education in a Crisis', Journal of Development Economics 74.1:53-85

UNHCR (1994) UNHCR's Operational Experience with Internally Displaced Persons, September, available at www.unhcr.org/3d4f95964.html (accessed 20 October 2011)

UNHCR/OSCE (2002) Ninth Assessment of the Situation of Ethnic Minorities in Kosovo, United Nations High Commissioner for Refugees / Organization for Security and Cooperation in Europe, 31 May

USAID (2007) Role of Education and the Demobilization of Child Soldiers, USAID Issue Paper 1

Walter, B.F. (2004) 'Does Conflict Beget Conflict? Explaining Recurring Civil War', Journal of Peace Research 41.3: 371-88

Ward, J. (2002) 'Gender-Based Violence in Refugee Settings', The Lancet 360: s13-s14

World Bank (2005) Reshaping the Future - Education and Post-conflict Reconstruction, Washington DC: The World Bank

(2003) Education in Rwanda: Rebalancing Resources to Accelerate Post-Conflict Development and Poverty Reduction, Human Development Department, Africa Region, Report 26038-RW, Washington 